\title{
Biology of Loch Ness
}

\section{Author(s): James Murray}

Source: The Geographical Journal, Vol. 24, No. 4 (Oct., 1904), pp. 442-443

Published by: geographicalj

Stable URL: http://www.jstor.org/stable/1775954

Accessed: 27-06-2016 07:17 UTC

\section{Your use of the JSTOR archive indicates your acceptance of the Terms \& Conditions of Use, available at}

http://about.jstor.org/terms

JSTOR is a not-for-profit service that helps scholars, researchers, and students discover, use, and build upon a wide range of content in a trusted digital archive. We use information technology and tools to increase productivity and facilitate new forms of scholarship. For more information about JSTOR, please contact support@jstor.org.

The Royal Geographical Society (with the Institute of British Geographers), Wiley are collaborating with JSTOR to digitize, preserve and extend access to The Geographical Journal 
it is difficult to explain it, as was attempted in the case of Lake Geneva, by assuming an oscillation of part of the loch.

The polynodal seiche, whose period is 8.8 minutes, is always of small amplitude, but sometimes very regular. There are also oscillations of shorter period, but they do not occur regularly enough to allow of their measurement with any degree of accuracy. On one or two occasions there were embroideries on the curve, which may have been due to transverse seiches. Owing to the narrowness of the loch, the period of such a seiche would only be about one minute. These embroideries may be due to a variety of causes, such as the wash of steamers, the opening of the lock-gates in the canal, etc. It will only be possible to determine whether they are vibrations or transverse seiches by simultaneous observations at the two sides of the loch.

The range of atmospheric conditions at Fort Augustus included thunderstorms, and eartbquakes also occurred, but these had no very marked influence on the loch. It seems probable that the cause of seiches is sudden local variations of atmospheric pressure ; and this view is supported by the records of a barograph at Fort Augustus. The polynodal seiches, and perhaps the uninodal and binodal seiches also, may be started by sudden gusts of wind. The wind blows down the various glens in strong, almost vertical gusts, and this may be sufficient to start the oscillation.

All the speculations, however, regarding the causes of seiches can only be satisfactorily tested by quantitative measurements of the forces at work, and it is hoped that something will be done in this direction in the summer of 1904 .

\section{BIOLOGY OF LOCH NESS.}

\section{By JAMES MURRAY.}

The observations made by the members of the Lake Survey during the summer and autumn of 1903 showed that, while every part of the loch, down to the deepest part of the bottom, has its inhabitants, there is one area in which life, if not altogether absent, is very rare. This area is the open water of the loch from a depth of 300 feet to the bottom. Fish may live in this region, but none of the animals obtainable by our nets have been collected in it.

In studying the distribution of organisms in the loch, it is convenient to follow Forel in dividing it into three regions-the Pelagic, the Littoral, and the Abyssal. Each of those regions possesses a distinct association of species.

In the open water of the loch there is a small number of animals and plants, distributed with considerable uniformity throughout. Owing probably to the small annual range of temperature occurring in such a large lake, this pelagic association changes very little throughout the year, the only change observed being the disappearance of a few species in winter. The vertical distribution of the species is very unequal, some having a greater vertical range than others. Life is usually densest at some little distance from the surface (say 20 to 50 feet), but at night there is a distinct migration of many species towards the surface.

'I'he shores of the loch support an abundant flora and fauna. The flowering plants, mosses, and algæ, which grow attached to the rocks or stones of the shore, shelter an immense number of microscopic animals. A great many of the species characteristic of this region extend to a very considerable deptb, beyond the limits at which plants cease. The majority of the Entomostraca and many species of Rotifera and other microscopic animals have been dredged at a depth of nearly 300 feet. It is supposed that the abundant deposit of vegetable débris on the bottom of the loch takes the place of growing plants in maintaining this rich fauna.

The abyssal fauna includes a few species which are generally distributed all 
over the bottom from a depth of 300 feet to the deepest parts of the loch. Below 300 feet the majority of the littoral species cease. A few, such as Hydra rubra, some water-mites, and a Limnæa, found at depths of from 400 to 600 feet, were so rare that they may be regarded as casually present.

The ahyssal fauna includes species representing most of the great groups of aquatic animals. There are Insects, Molluscs, Entomostraca, Worms (Oligochœtes, Turbellarians, Nematodes, and one Rotifer), and Infusoria. These species are not confined to the deeper parts of the loch. The majority of the species range right up to the shore. So far as we have gone, we have found no peculiar species in the abyssal fauna. It seems to be merely an extension of the littoral fauna, including those species which are best able to adapt themselves to the reculiar conditions of the abyssal region. When brought to the surface, the abyssal animals appear to suffer no inconvenience, and thrive well in bottles. A more critical examination of the species by experts may modify our conclusion as to the origin of the abyssal fauna. In one group only, the Rotifera, have we found what may be incipient species, the eyes being often reduced in size or altogether absent.

After the reading of the above papers, Sir John Murray, Lord Belhaven, Prof. Garwood, Dr. H. R. Mill, Mr. Ravenstein, Mr. Chisholm, Mr. Freshfield, and the Chairman took part in a long and interesting discussion on the various problems raised by the communications, and the hope was expressed that these observations and investigations would be continued and extended.

Sir John Murray stated that arrangements were in progress to make a much more detailed investigation of the temperatures and seiches in Loch Ness during the coming summer. All the principal Scottish lochs had now been surveyed, but during next year the survey of the smaller ones would be undertaken, and, so far as possible, co mpleted.

\section{ON MOUNTAINS AND MANKIND.*}

\section{By DOUGLAS W. FRESHFIELD.}

A GEOGRAPHER or traveller who has been called upon to preside over the meetings of our Section of the British Association may be excused for feeling some hesitation as to the character he shall give to the address which custom compels him to deliver. He cannot but be aware that his audience, while it includes not a few experts, probably far better qualified tban himself to take the chair, is composed mainly of those whose concern in geography can only be a general and occasional one.

To compose a summary of the geographical events of the year would be a simple and obvious expedient, were I not conscious that in this I have been forestalled by the indefatigable President of the Royal Geographical Society. Again, to consider the progress of geography during, say, the last quarter of a century, might be instructive to " the general." On the other hand, on his special subject, your President may possibly be able to add something to the common stock by way of observation or suggestion.

Bearing in mind the, from the point of view of posterity, almost excessive energy with which the nineteenth century carried on the exfloration of the globe,

* Presidential Address to the Geographical Section at the Cambridge Meeting of the British Association, August, 1904. 